\title{
Power Loss Minimization in Cascaded Multi-Level Converters for Distribution Networks
}

\author{
M. A. Rehman-Shaikh, P. D. Mitcheson and T. C. Green \\ Control and Power Research Group, EEE Department, Imperial College London, asim.rehman@imperial.ac.uk
}

\begin{abstract}
This paper compares two structures of cascaded multilevel converter for $11 \mathrm{kV}$ and $33 \mathrm{kV}$ distribution networks for the two main competing IGBT technologies (Non Punch Through and Punch Through) with the intention of minimizing power loss. The traditional cascaded converter, which has equal-sized cells in its chain and the recently proposed chain with a ternary relationship between its dc-link voltages are both investigated. Models with 81 and 27 levels are developed for both kinds of converter after selection of suitable IGBT devices for comparative analysis. The total power losses in the IGBTs and diodes of each cell in the chain are estimated by simulation (160 separate cases) and it has been concluded that the conduction losses are dominant in both types of converters in NPT and PT IGBTs for $11 \mathrm{kV}$ and $33 \mathrm{kV}$ systems. The results have shown that the equal-sized converter is only likely to be useful in one case (27-levels in the $33 \mathrm{kV}$ system) whereas the ternary-sequence converter produces lower losses in all the other cases. Further, it was found that the PT IGBT is the better option for ternary sequence whereas the NPT IGBT is better for the equal-sized converter.
\end{abstract}

\section{INTRODUCTION}

Nowadays, it is hard to connect a single power semiconductor switch directly to medium voltage grids $(11 \mathrm{kV} / 33 \mathrm{kV})$ because of the limitation in device ratings. Multilevel converter technology has emerged as an effective option in the area of high-power, medium - or low voltage control $[1,2]$. The main motivation for multilevel topologies is the increase of power rating, the reduction of voltage stress on the power switching devices and the generation of high quality output voltages. As the number of voltage levels increases, the harmonic content of the output voltage waveform decreases significantly. The cascaded-cell converter is well suited for harmonic/reactive compensation and other utility applications [3].

The cascaded-cell converter is constructed from a series arrangement of cell modules. The cascaded multilevel converter has two main types: The traditional as in Fig.1, "equal-rated" converter whose output voltage has $2 \mathrm{~N}+1$ levels. Second is a family of multilevel converters recently proposed [4] having "ternary sequence" DC-Link voltages in which each cell has the relationship of $1 \mathrm{Vdc}, 3 \mathrm{Vdc}, 9 \mathrm{Vdc} . .$. $3^{(\mathrm{N}-1)} \mathrm{Vdc}$, as shown in Fig.2. With this arrangement, the number of levels of the output waveform equals $3^{\mathrm{N}}$ where $\mathrm{N}$ is total number of cells.

Both options, i.e. equal-rated and ternary-sequence are attractive due to linear component count and modularity but their assessment on the basis of overall power losses will contribute in determining the right topology in distribution

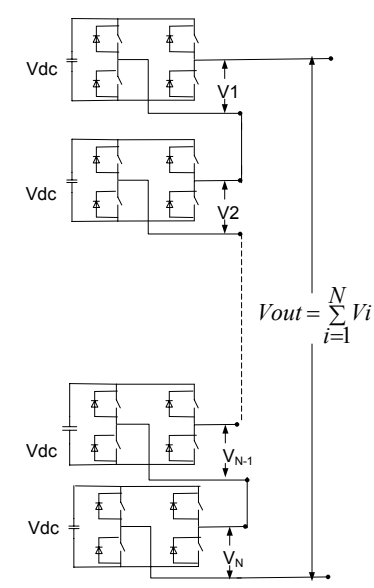

Figure. 1. Equal rated converter

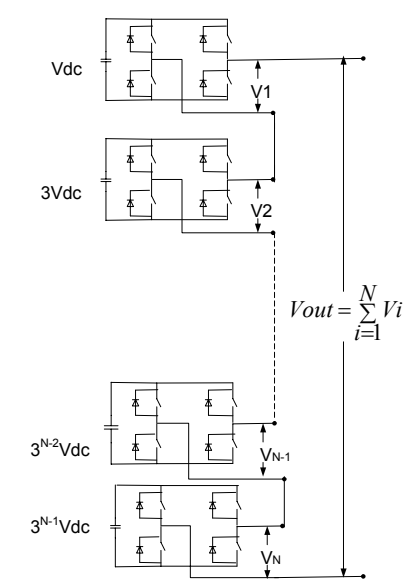

Figure.2. Ternary-sequence converter

\begin{tabular}{|c|c|c|}
\hline Converter & $\begin{array}{c}\text { Input voltage } \\
\text { (p.u) } \mathbf{1} / \mathbf{3}^{\mathbf{n}}\end{array}$ & $\begin{array}{c}\text { Switching frequency (Hz) } \\
\left(\mathbf{2}^{*} \mathbf{3}^{\mathbf{n}}-\mathbf{1}\right) \boldsymbol{f}_{\boldsymbol{o}}\end{array}$ \\
\hline Cell I & $1 / 27$ & $53 f_{o}$ \\
\hline Cell II & $1 / 9$ & $17 f_{o}$ \\
\hline Cell III & $1 / 3$ & $5 f_{o}$ \\
\hline Cell IV & 1.0 & $f_{o}$ \\
\hline
\end{tabular}

Table. 1. Design features of ternary-sequence converter

networks. It is emphasized that the IGBT device technologies used in the evaluation will be subject to change as new devices will appear on the market but the main purpose is to evaluate the converters rather than the devices.

The key features of the design of a ternary-sequence converter are mentioned in table 1 . The maximum output voltage of the highest cell is chosen as the base value for table.1. The total voltage achieved from this converter is [ $(3 \mathrm{~N}-$ $1) / 2]^{*} \mathrm{Vdc}$ at a fundamental frequency $f_{o}$. Table 1 is used in our modelling of this converter.

\section{A. Working of an H-bridge}

Fig. 3 shows one H-bridge cell of a multilevel converter. The cell consists of four power switches, which can be IGBT, GTO or other power devices, and a DC source.

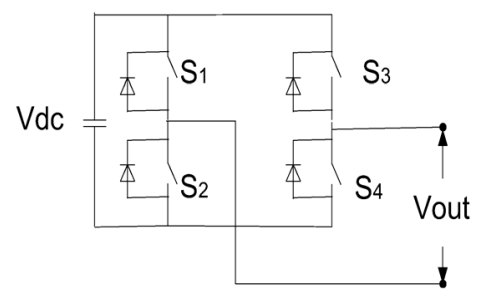

Figure. 3. Construction of H-bridge cell 


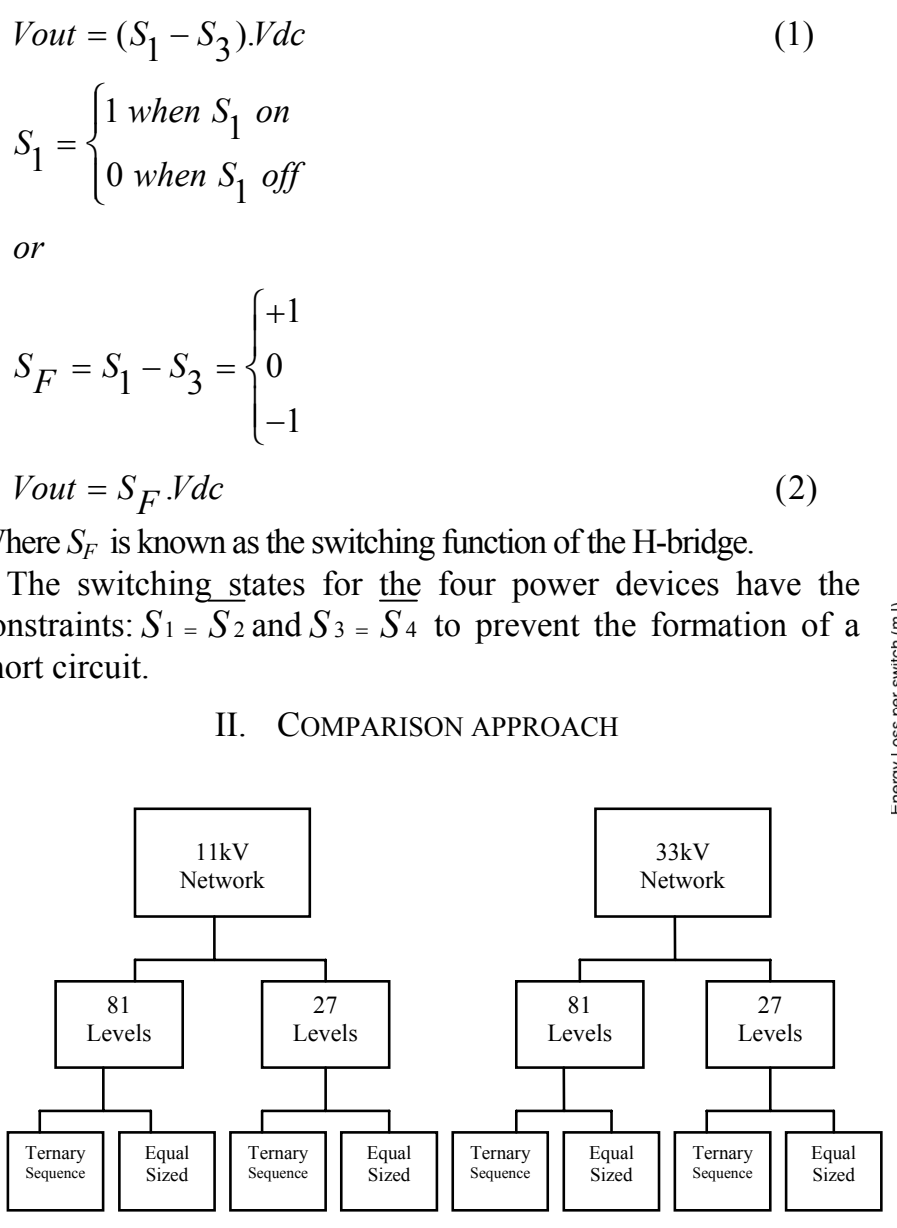

Figure. 4. Technology comparison for two types of cascaded converters

Of the available ternary sequence levels [3, 9, 27, 81, $243 \ldots . .$.$] and equal sized converter levels [3,5,7,9 \ldots],$.81 and 27 levels were chosen for the converters because the next higher available number of levels in the ternary sequence converter would involve too many cells in the equal-rated case (121 cells), and less than 27 levels in the ternary-sequence (9levels) would result in poor harmonic quality. (Fig. 4)

\section{EVALUATION CRITERIA}

The trend in power semiconductor devices is towards IGBTs [5], which have two main competing technologies, conventional

NPT (Non Punch Through) IGBTs [6] and PT (Punch Through) IGBTs [7]. Due to the market urge for smaller units and the increased awareness about power loss the question of inverter efficiency vs. costs has become a major issue. A careful study was performed on $600 \mathrm{~V}, 1200 \mathrm{~V}, 1600 \mathrm{~V} / 1700 \mathrm{~V}$, $3300 \mathrm{~V}$ and $6500 \mathrm{~V}$ classes on both types.

It was initially thought that the device with faster switching frequency will produce more switching losses compared to the one at lower switching frequency. This may be the case if they have the same voltage and current rating but it is not obvious when comparing two differently rated devices which normally happen in multilevel converters. In the ternary-sequence
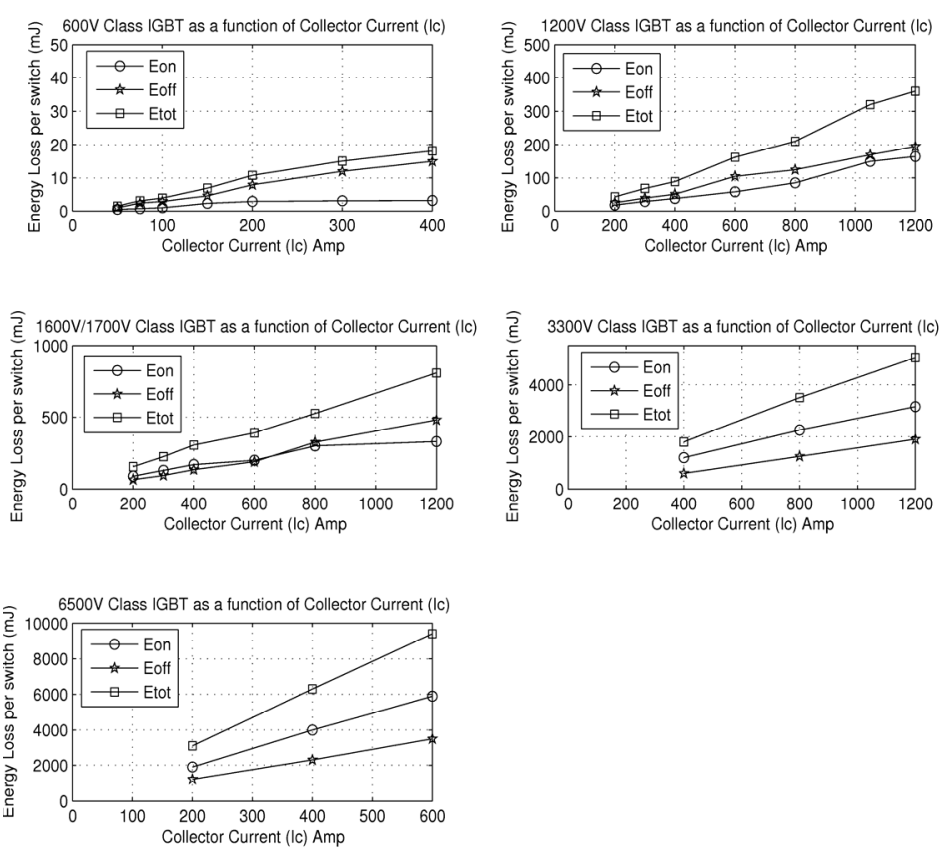

Figure. 5. Energy loss per switch of various classes of IGBT

converter the cell with the highest switching frequency cell has the lowest voltage and so it is not immediately obvious which cell suffers the highest switching loss. For example, one $6500 \mathrm{~V}$ device can yield more switching loss at the fundamental frequency than a $600 \mathrm{~V}$ device switching at more then $2.5 \mathrm{kHz}$ at same ampere rating as shown in Fig. 5. Various trade/off comparisons between switching losses and on-state voltage drops were made while selecting the device for modelling with both the types of IGBT technologies.

Now looking at the switching loss energies of $600 \mathrm{~V}$ IGBT

for the same rated current are smaller by a factor of 4 to 5 as compare to $1200 \mathrm{~V}$ IGBT. It means that, by connecting two series $600 \mathrm{~V}$ devices features only less then $50 \%$ of switching losses of one $1200 \mathrm{~V}$ IGBT while increasing the conduction losses twice of $1200 \mathrm{~V}$ IGBT. Interestingly $3300 \mathrm{~V}$ and $6500 \mathrm{~V}$ device has significantly higher turn on losses then turn off losses. There is a high loss energy difference exists between the voltage classes of $1700 \mathrm{~V}, 3300 \mathrm{~V}$ and $6500 \mathrm{~V}$.

\section{CASCADED MULTILEVEL CONVERTER MODELLING}

A model was developed in the PLECS/SIMULINK simulator similar to the one shown in fig. 1 and fig. 2 which had two main objectives. First, the formation of staircase waveform using chain-cells. Second, the power loss evaluation of high voltage IGBTs and inverse diodes used in the construction of cascaded converters. It can be modified for any number of cells. The device models of IGBT and inverse diode approximate on state voltage drop by a slope resistance and a fixed voltage.

\section{A. Modulation Strategy}

In this model a reference signal of a fundamental sinusoidal waveform is fed into quantizer function block whose output is 
then biased by the half of the number of required voltage levels. This biased output will be used next to find the states (either $+1,0$, or -1 ) of the corresponding cell. As all methods do, it synthesizes the output voltage waveform using the two voltage levels closest to the desired output voltage (reference voltage). This reduces the voltage deviation (error), hence distortion of the voltage waveform with respect to the reference voltage, thus improving the quality of the voltage waveform (hence currents) without the need for an increase in the switching frequency. In this particular case, the reference voltage is synthesized (or approximated) using only the closest voltage level. This modulation strategy is chosen because of its simplicity for analyzing the internal switching pattern of each cell in both cascaded-cell converters.

81 and 27 levels are generated by using 4 and 3 cells for ternary-sequence whereas 40 and 13 cells are required to produce the same number of levels with equal-rated converter. A Look-up table is used to store switching function for each cell. DC-link voltage of each cell in the chain, MVA capacity of load, power factor and switching frequency of each converter are adapted. For the evaluation, the converters are assumed to be operating in steady state at constant case temperature of $T c=80^{\circ} \mathrm{C}$ and with a maximum junction temperature of $T j, \max =125^{\circ} \mathrm{C}$. The power factor of load is 0.9 which is common in distribution networks.

We can observe from fig. 6 that cell-IV is the slowest (fundamental frequency) and cell-I is the fastest $(2650 \mathrm{~Hz})$ as noted in the table.1. For the equal-sized converter, 40-cells which switch at fundamental frequency produce the same 81levels and the resulting output waveform was identical as shown in fig. 7 .

Note that to avoid the start up transient we consider the interval from $20 \mathrm{~ms}$ to $40 \mathrm{~ms}$. The same strategy was repeated to produce 27 levels from 3 and 13 cells.

$$
\left|v_{\text {ref }}-v_{o}\right| \leq \frac{V d c}{2}
$$

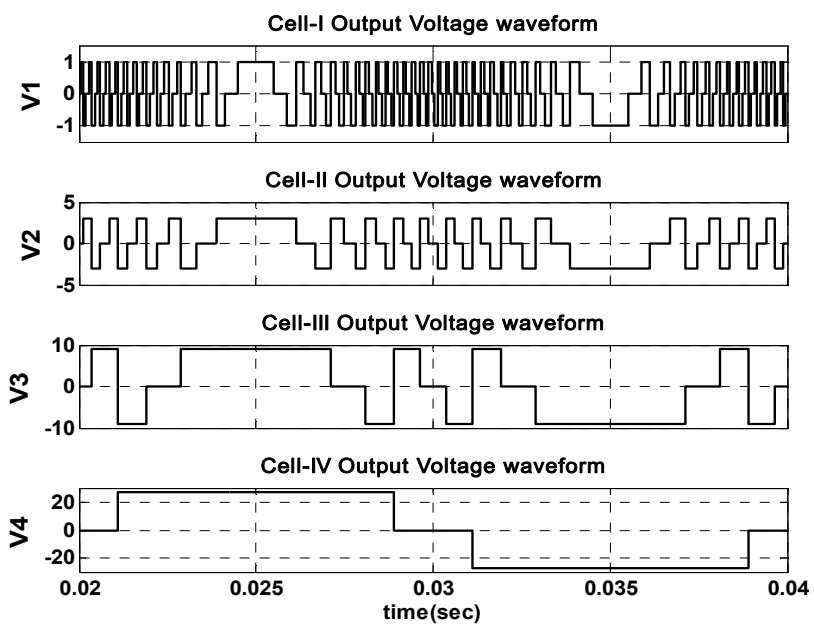

Figure. 6. Output waveform of 4-cell (ternary sequence converter)

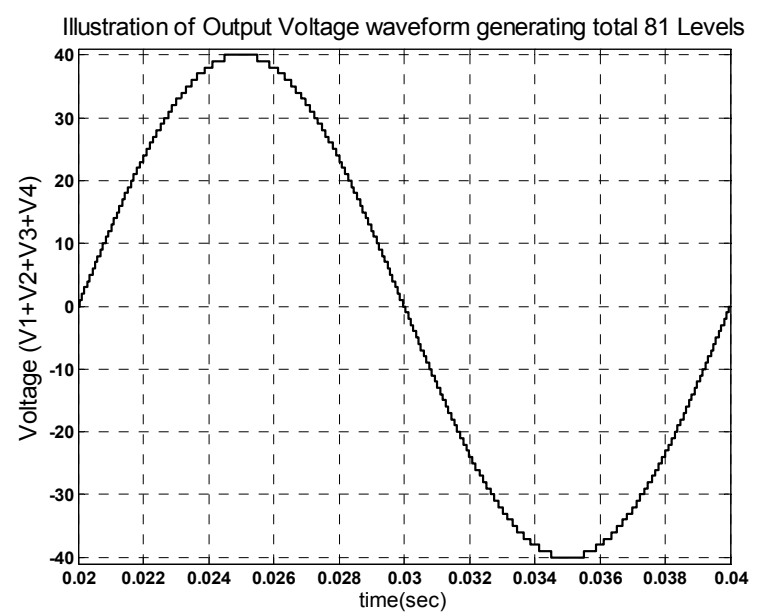

Figure 7. 81-level Out-put waveform

\section{NPT VERSUS PT TECHNOLOGY}

This section is intentionally placed before we go in the details of loss calculation criteria and derivation of formulae. The IGBT is ideally suited for blocking high voltages. The differences between the NPT and PT devices are at the turn-off transient and the on-state voltage drop. The fall in the IGBT current during turn-off has two time stages; first is usual time which corresponds to the usual expected turn-off of the device and second is the tailing of the collector current due to the stored charge in the n-drift region. The tail current can be reduced if there is significant recombination within the $n$-drift region. It is desirable that the excess carrier lifetime is large to reduce the on-state voltage drop, but this increases the duration of the tail current. This will result in additional switching losses within the device. The removal of stored charge can be greatly enhanced with the addition of an $n+$ layer which acts as a sink for the excess holes and shortens the tail time as done in PT IGBT (see fig. 9). This extra $n+$ layer greatly enhances the removal rate of holes (minority carriers) from the drift region and shortens the tail time, but at the same time, on-state losses are higher in the PT devices because the hole injection efficiency from the collector is reduced due to the presence of the $\mathrm{n}+$ region. This leads to poor conductivity modulation of the drift region.
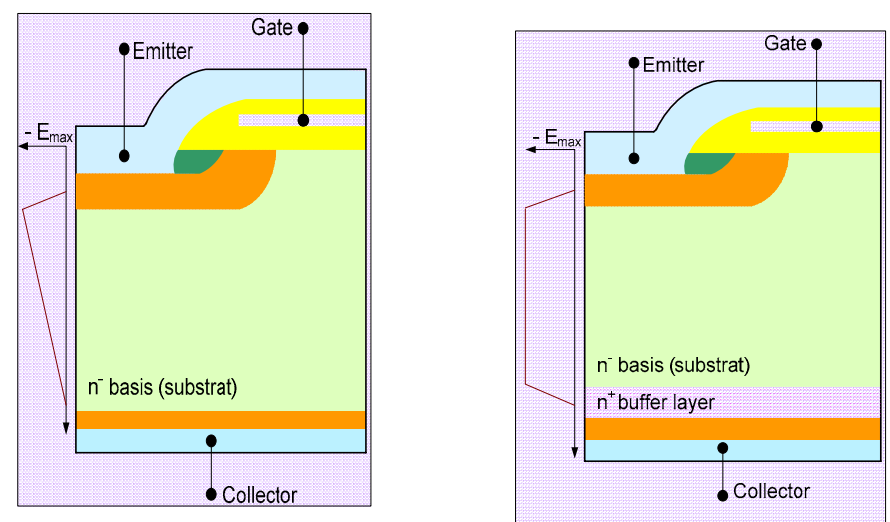

Figure. 8. Standard NPT IGBT structure Figure. 9. PT IGBT structure 
Loss evaluation of both kinds of cascaded converters was performed in our study using NPT and PT IGBTs to see if the device technology, specifically the different balance of conduction and switching loss, will affect the choice of converter. The results were aligned with the theory presented and overall comparison is illustrated in section VIII.

\section{POWER LOSS CALCULATION METHODOLOGY}

The sum of the conduction and switching losses is a good estimation of the total power loss in the device.

\section{A. Thermal criteria}

Thermal design is indispensable when using the semiconductor for high power application. Power dissipation must be rapidly removed from the internal wafer through the package and ultimately to the cooling medium.

The concept of thermal resistance $\left(\mathrm{R}_{\mathrm{TH}}\right)$ is used when considering heat dissipation. The losses will lead to heat generation within the device, and consequently a rise in temperature until the rate of heat dissipation matches the loss. We can say that;

$\mathrm{R}_{\text {TH IGBT-Heat Sink }} \alpha 1 / \mathrm{A}_{\text {IGBT }}$

Heat flow (power dissipated) $=\mathrm{T}_{\mathrm{IGBT}}-\mathrm{T}_{\text {Heat Sink }} / \mathrm{R}_{\mathrm{TH}}$

Rate of heat flow (Power dissipated) $\alpha 1 / \mathrm{R}_{\mathrm{TH}}$

$$
\alpha \text { Area }
$$

Rate of heat flow (Power dissipated $)=\mathrm{k} *$ Area

$\mathrm{P}_{\mathrm{LOSS}}=\mathrm{k} *$ Area

Here, we arrive to an important argument from the designer's point of view that power loss per unit area must stay constant (k).

B. Analytical study of device for scaling voltage/current with size

- When blocking voltage of the device is constant and current is variable

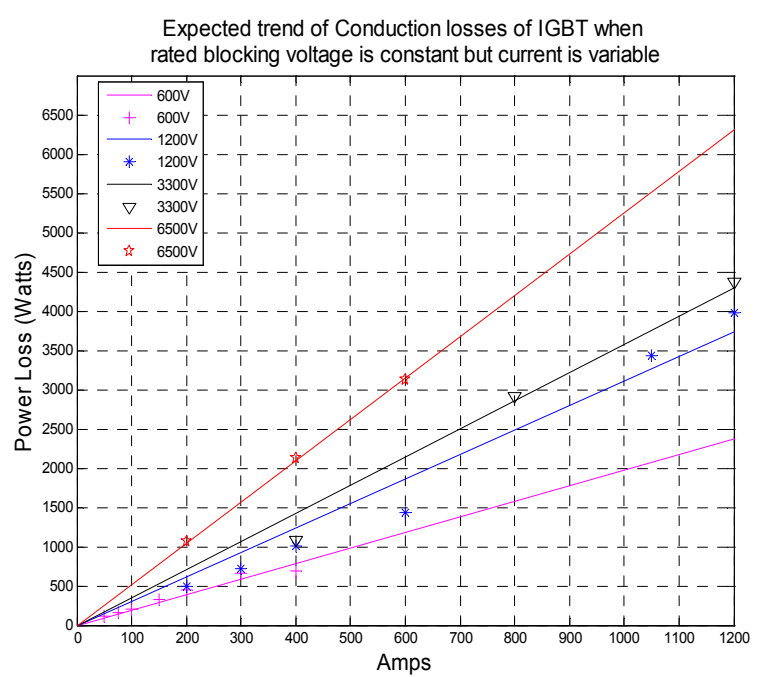

Figure. 10. Expected trend of power losses (Current variable)
$P_{\text {Loss }}=I^{2} * R+V_{\text {on }} I$

$P_{\text {Loss }}=I^{2} \rho \frac{L}{A}+V_{\text {on }} I$

$\frac{P_{\text {Loss }}}{\text { Unit Area }}=I^{2} \rho \frac{L}{A^{2}}+\frac{V_{\text {on }} I}{A}$

From designer view point, the device should have constant $\frac{P_{\text {Loss }}}{\text { Unit Area }}$ As $V_{\text {block }}$ is constant means drift length is constant soas $V_{\text {on }}$;

hence we get; $I^{2} \alpha A^{2}$ OR

$A \alpha I$

At this point the rated power loss (refer small points in fig. 10) was calculated by using the data sheets $[6,7]$ of the manufacturer to see the trend and prove that our derived relationship is aligned. Fig. 10. depicts the same relationship (best fit was straight lines for the rated power loss) as established in equation (7).

- When blocking voltage of the device is variable and current is constant

Using equation (6)

$\left[\frac{P_{\text {Loss }}}{\text { UnitArea }}\right] A^{2}=\rho I^{2}\left(\frac{V_{\text {block }}}{E_{\max }}\right) I^{2}+V_{\text {ON }} I A \because V_{\text {block }}=E_{\max } \cdot L_{\text {drift }}$

$A^{2}-\frac{V_{O N} I A}{k}-\frac{V_{\text {block }} \rho I^{2}}{k \cdot E_{\max }}=0$ (Quadratic form $)$

wherek $=\frac{P_{\text {Loss }}}{\text { Area }}$

$A=\frac{\frac{V_{O N} I}{k} \pm \sqrt{\left(\frac{V_{O N} I}{k}\right)^{2}-\frac{4 \rho V_{\text {block }} I^{2}}{k \cdot E_{\max }}}}{\text { OR }}$

$A=\frac{I}{2}\left[\frac{V_{O N}}{k}+\sqrt{\left(\frac{V_{O N}}{k}\right)^{2}+\frac{4 \rho V_{\text {block }}}{k \cdot E_{\max }}}\right]$

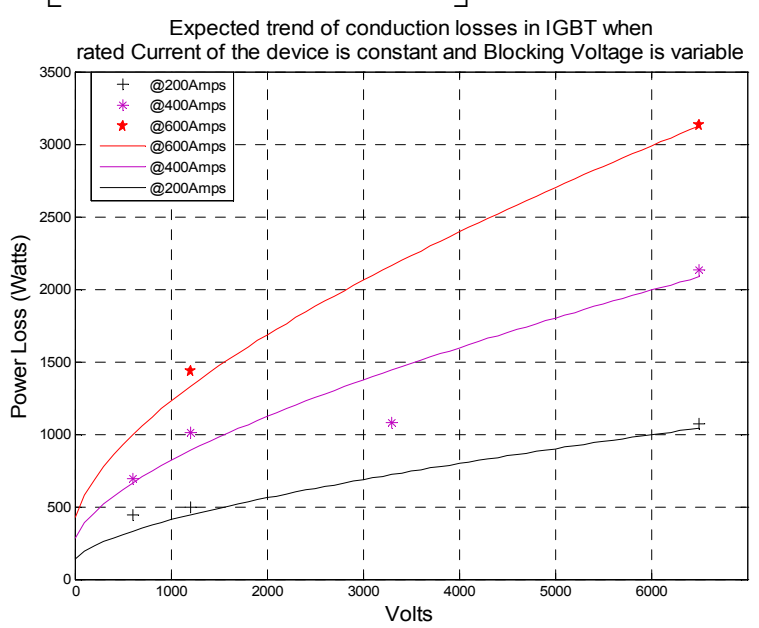

Figure. 11. Expected trend of power losses (Voltage variable) 
In the above equation $V_{O N}$ is constant because the doping profile of the device is assumed constant so far. Fig. 11 shows close verification of our established analytical relationship of equation (9). Current work is going on to develop equations for switching losses based on device ratings.

\section{Loss calculation from the model}

The losses are dependent on the conduction ratio of the IGBT and the reverse conducting diode. If ' $\mathrm{m}$ ' is the total number of levels achieved then the total number of IGBTs is $2 *(\mathrm{~m}-1)$ and $2 *(\mathrm{~m}-1)$ diodes are required.

The average conduction losses $P_{\text {cond }}$ due to IGBT and inverse diode in both converters can be expressed as:

$P_{\text {cond }}=\frac{1}{T_{0}}\left[\int_{0}^{T} V f(t) i(t) d t\right]$

where $V_{f}(t)=v_{\text {on }}+\operatorname{Ri}(t)$

$P_{\text {cond }}=$ Power loss due to conduction of a switch

$i(t)=$ switch current

$V_{f}=$ forward voltage drop of the device

$v_{o n}=$ fixed component of forward voltage drop of a device

$T_{0}=$ fundamental period

$T=$ Conduction time of switch

$R=$ Slope resistance of device

The conduction losses depend on the number of devices in the output current path. These number of devices depends upon which switch is active i.e. its state (ON-OFF) in each converter. The model data for the IGBT and inverse diode modules are based on their respective data-sheet values from
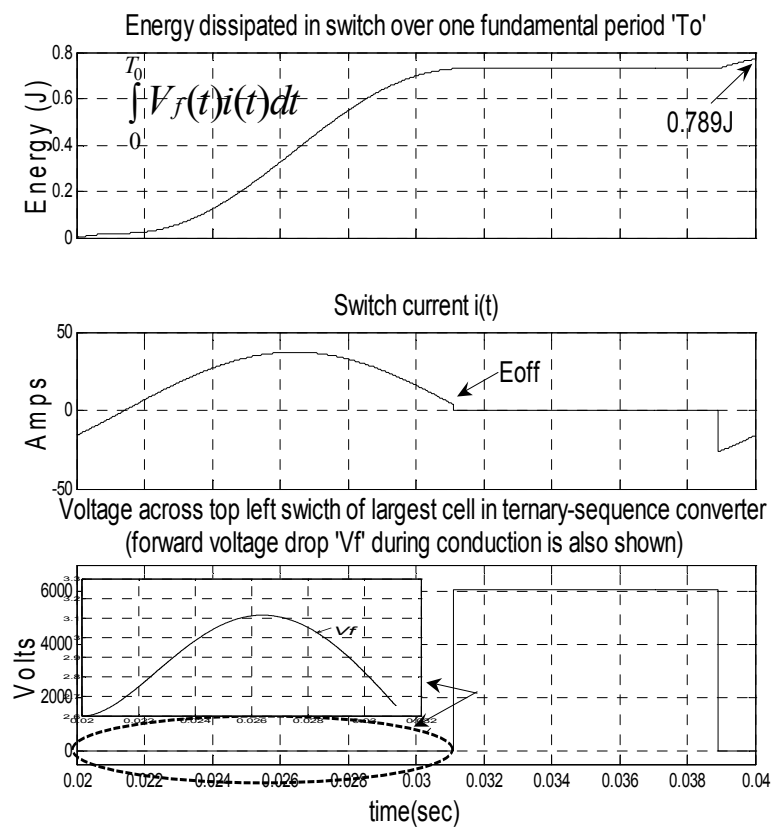

Figure. 12. Voltage and current variation with energy dissipation (example case) the manufacturer $[6,7]$.

The calculation was made for each cell and then losses in all the cells connected in the chain is summed over one fundamental period ' $T_{0}$ '. An example of the conduction loss calculation is shown in fig 12 .

\section{Switching losses}

Switching losses can be estimated from the manufacturer's graphs of switching energy loss as a function of current. Equation (11) is used for the equal-sized converter because $f_{S W}$ and $E_{t o t}$ of all the cells are the same.

$P_{s w}=4 *\left\{N\left(E_{t o t} * f_{S W}\right)\right\}$

Where;

$P_{s w}=$ Switching Power loss of a cell

$E_{\text {tot }}=$ Average total energy loss during on and off transition of the switch

$f_{s w}=$ Switching frequency of the cell

$\mathrm{N}=$ Number of cells in the chain

The ternary-sequence converter requires individual calculation for each cell because each cell has different $f_{S W}$ and $E_{t o t}$. The instant of turn on and turn off of each switch for every cell can be calculated during the simulation over a range of MVA capacity of multilevel converters to calculate the switching losses. Equation (12) is used to estimate the total switch loss of a cell in ternary-sequence converter in which $N_{S W}$ is the number of switching cycles per fundamental cycle.

$$
\begin{gathered}
P_{s w}=4 . \sum_{k=1}^{N_{S W}} E_{o n}(k)+4 . \sum_{j=1}^{N_{S W}} E_{o f f}(j) \\
\text { where } N_{s W}=\operatorname{round}\left(f_{s w} / f_{o}\right)
\end{gathered}
$$

It should be noted that diodes mainly experience turn off losses. Conduction and switching losses are summed over one fundamental period of the output frequency. Total number of devices connected in both converters is considered. Diode reverse recovery energy is added to each turn-off energy dissipation per switching pulse. The average loss for IGBT and inverse diode in circuit with sinusoidal output voltage can be written as:

$$
P_{a v}=P_{c o n d}+P_{s w}
$$

\section{IMPLEMENTATION OF CASCADED CONVERTERS IN DISTRIBUTION NETWORKS - FINDINGS}

These topologies were simulated on $11 \mathrm{kV}$ and $33 \mathrm{kV}$ systems. DC-link voltages, output voltages and switching frequency were calculated to construct $11 \mathrm{kV}$ and $33 \mathrm{kV}$ phase voltages with judicious selection of devices for both the types of IGBT. Conduction Losses were dominant in comparison to switching losses in both topologies. 


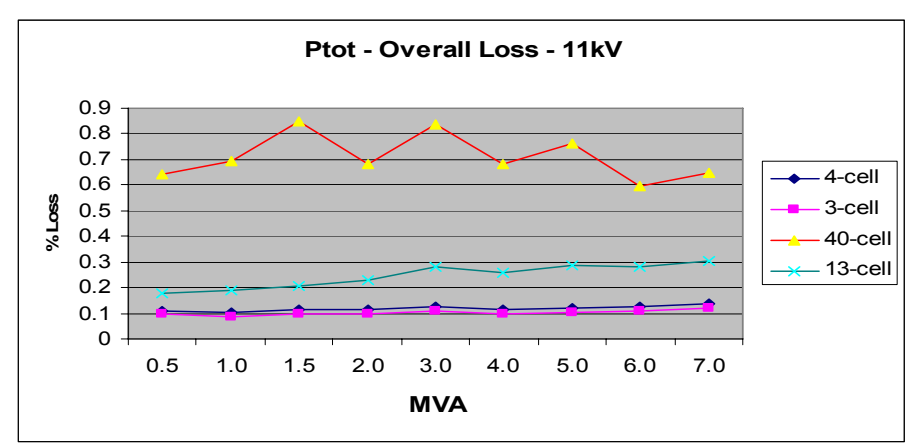

Figure. 13. Overall power losses in both types of converters in $11 \mathrm{kV}$ system

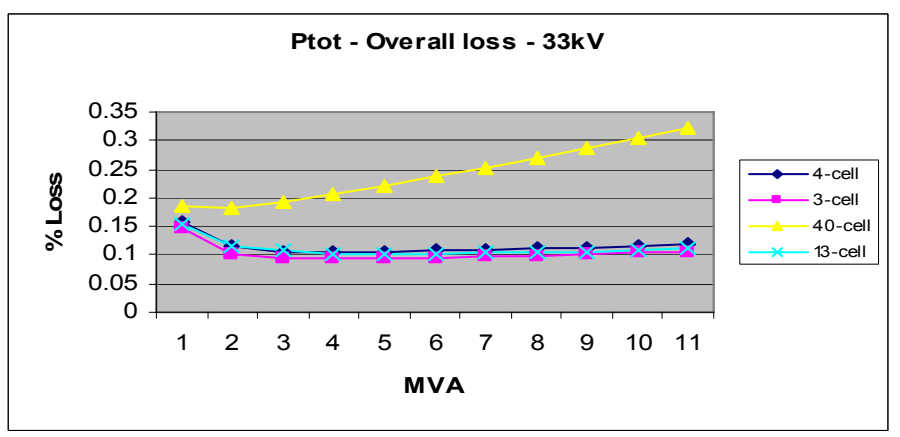

Figure. 14 . Overall power losses in both types of converters in $33 \mathrm{kV}$ system

\section{A. $\quad 11 \mathrm{kV}$ and $33 \mathrm{kV}$ Network}

Results depicted in Fig. 13 that the 81 level $11 \mathrm{kV}$ system using the equal-sized topology (40-cell) has five times more losses than the ternary sequence topology (4-cell).

Further, in the $33 \mathrm{kV}$ system, the equal-sized converter has two and half times more losses than ternary-sequence as shown in Fig. 14.

\section{LOSS COMPARISON OF NPT AND PT TEHNOLOGY}

A thorough investigation of NPT and PT IGBTs showed that the PT, which has less switch loss, is a better technology for ternary-sequence converter when used in distribution networks because of the high switching frequency of the cells. On the other hand, its good to apply NPT IGBT for equal-rated converters because this a conduction loss dominated converter topology and the NPT has better conductivity modulation (Table 2).

\begin{tabular}{|c|c|c|c|}
\hline Levels & Cell & $11 \mathrm{kV}$ system & 33kV System \\
\hline \multirow[b]{2}{*}{81} & $\begin{array}{c}\text { (T.S) } \\
4\end{array}$ & $\begin{array}{l}\text { NPT IGBT has } 5-8 \% \\
\text { more losses }\end{array}$ & $\begin{array}{l}\text { NPT IGBT has } 10-25 \% \\
\text { more losses }\end{array}$ \\
\hline & $\begin{array}{c}\text { (E.S) } \\
40\end{array}$ & $\begin{array}{c}\text { NPT IGBT has } 25- \\
50 \% \text { more losses }\end{array}$ & $\begin{array}{l}\text { PT IGBT has } 25-50 \% \\
\text { more losses }\end{array}$ \\
\hline \multirow[b]{2}{*}{27} & $\begin{array}{c}\text { (T.S) } \\
3 \\
\end{array}$ & $\begin{array}{l}\text { NPT IGBT has 5- } \\
10 \% \text { more losses }\end{array}$ & $\begin{array}{c}\text { NPT IGBT has } 10-25 \% \\
\text { more losses }\end{array}$ \\
\hline & $\begin{array}{c}\text { (E.S) } \\
13\end{array}$ & $\begin{array}{l}\text { PT IGBT has } 15- \\
30 \% \text { more losses }\end{array}$ & $\begin{array}{l}\text { PT IGBT has 5-10\% } \\
\text { more losses }\end{array}$ \\
\hline
\end{tabular}

Table 2. Overall comparison of NPT and PT IGBT on $11 \mathrm{kV} / 33 \mathrm{kV}$ system

\section{CONCLUSIONS}

81 and 27 levels converter (equal-rated and ternarysequence) are modeled and compared on $11 \mathrm{kV}$ and $33 \mathrm{kV}$ systems by using different cell configurations. The IGBT is used as a switching device in the modeling of these converters. There are two main competing technologies, conventional NPT IGBTs and PT IGBTs which are widespread in the market. A detailed survey on both types of IGBT was carried out on the basis of forward conduction and switching characteristics.

The objective of the modeling undertaken was to calculate the switching and conduction losses for NPT and PT IGBT and inverse diode (used in each cell) in the chain on $11 \mathrm{kV}$ and $33 \mathrm{kV}$ system to calculate overall losses in the two types of cascaded converters. It is demonstrated that the ternarysequence converter is superior to the equal rated converter with 81 levels in both $11 \mathrm{kV}$ and $33 \mathrm{kV}$ systems. However with 27 levels, the equal-rated converter is also a suitable option for $33 \mathrm{kV}$ system.

This analysis stands true for both NPT and PT types of IGBTs. Overall the PT IGBT has less losses for both designs of cascaded converter. But when comparing both PT and NPT IGBT, it is preferred to use PT for ternary-sequence converter because of its low switching losses and use NPT for equal-rated converters because of low conduction losses.

Lastly, it should not be ignored that the equal-rated design offers integration of redundancy at lower cost and in a less complicated fashion than with the ternary-sequence converter (because it requires only one extra cell to cover for failure of any other cell in the chain).

\section{ACKNOWLEDGMENT}

This research is funded by Commonwealth Scholarship Commission under research grant ref. PKCS-2004-296.

\section{REFERENCES}

[1] Rodriguez, J., Jih-Sheng Lai and Fang Zheng Peng, "Multilevel inverters: a survey of topologies, controls, and applications" Industrial Electronics, IEEE Transactions on Volume 49, Issue 4, Aug. 2002 Page(s):724 - 738

[2] R. Teodorescu, F.Beaabjerg, J. K.Pedersen, E.Cengelci, S.Sulistijo, B.Woo, and P.Enjeti, "Multilevel converters - A survey," in Proc. European Power Electronics Conf. (EPE'99) Lausanne, switzerland, CDROM, 1999.

[3] F. Z.Peng, J. S.Lai, J. W.McKeever and J.VanCoevering, "A multilevel voltage-source inverter with separate DC sources for static var generation," IEEE Trans. Ind. Applicat., vol. 32, pp. 1130-1138, Sept. 1996.

[4] Y-S. Lai and F.-S. Shyu, "Topology of hybrid multilevel inverter," IEE Proc. -Electr, Power Appl, vol. 149, No. 6, Nov 2002.

[5] Ralph Teichmann and Steffen Bernet, "Three-Level Topologies for Low Voltage Power Converters in Drives, Traction and Utility Applications," IEEE transactions, 2003

[6] Data Sheets: EUPEC, Internet: www.eupec.com

[7] Data Sheets: EUPEC, Internet: www. mitsubishichips.com 